\title{
IMPROVING ROOTING AND GROWTH OF CONOCARPUS ERECTUS STEM CUTTINGS USING INDOLE-3-BUTYRIC ACID (IBA) AND SOME BIOSTIMULANTS
}

\author{
S.S.A. Abdel-Rahman; E.Y. Abdul-Hafeez and Asmaa M.M. Saleh \\ Ornamental Plants and Landscape Gardening Dept., Fac. Agric., Assiut Univ., Egypt
}

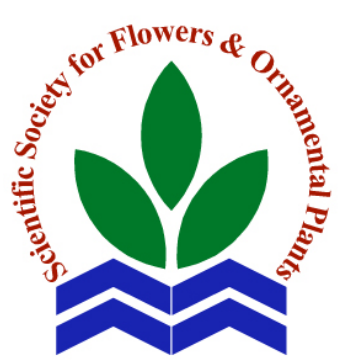

Scientific J. Flowers \& Ornamental Plants, 7(2):109-129 (2020).

Received: 20/4/2020

Accepted: $5 / 5 / 2020$

ABSTRACT: The current study was conducted to evaluate the effects of indole-3-butyric acid (IBA) at 100 ppm with or without biostimulants (Agrobacterium rhizogenes, seaweed extract and coconut water) as either a spray or drench for 3 minutes or 1 hour on rooting and growth parameters of three cutting types (tip, middle and basal) of Conocarpus erectus L. The data showed that the rooting percentage, root and vegetative characteristics of rooted cuttings were significantly increased by all treatments of IBA and/or biostimulants compared to the untreated cuttings. The individual treatments of seaweed extract and coconut water were more effective than IBA or $A$. rhizogenes alone. Seaweed extract as drench with or without IBA surpassed those of seaweed extract treatments as spray. Besides, the response of cuttings treated with coconut water for 1 hour was better than coconut water for $3 \mathrm{~min}$. Tip cuttings were significantly better than the middle and basal ones, especially in relation to rootability of cuttings.

Maximum rooting percentage and shoot characteristics of plants were obtained from tip cuttings treated with IBA + coconut water for 1 hour, followed by IBA + seaweed extract as drench. The highest rooting percentage was associated with high endogenous levels of phenols, indole acetic acid (IAA) and gibberellic acid (GA) as well as the lowest abscisic acid (ABA) level in cutting tissues and the anatomical structure of rooted cuttings. So, it can be recommended treating tip cuttings of $C$. erectus with either coconut water for 1 hour or seaweed extract as drench combined with IBA for enhancing the rooting percentage, root and shoot growth parameters as well as content of endogenous root promoting substances.

Key words: Conocarpus erectus, vegetative propagation, cutting type, IBA, biostimulants, seaweed extract, coconut water.

\section{INTRODUCTION}

Conocarpus erectus L. (buttonwood) is an evergreen shrub of family Combretaceae native to Florida's mangrove forest ecosystem in North America. C. erectus can tolerate severe desert summer temperatures which may reach $47^{\circ} \mathrm{C}$ and it can also grow in soils of very low fertility (Nelson, 1996). It is planted as an ornamental plant and in bonsai. $C$. erectus trees also are tough and long-lasting in the landscape. It is used for seaside planting, as a hedge, shade tree, residential street tree, buffer strips around parking lots and it also protects the soil during storm and helps to fix dunes (Gilman and Watson, 1993). The wood of C. erectus is durable and is used to make posts for turnery, railroad ties, fuel, buildings, boats, and charcoal. Also, it showed a number of medicinal properties including anticancer, antiviral, anti-diabetic, antioxidant, antibacterial and antifungal activities (Yasin and Al-Azawi, 2019). C. erectus is 
commercially propagated by stem cuttings, but this is an accompanied with reduced rooting capacity, long production time, weak growth and decreased survival rate of the rooted cuttings after the separation, particularly in relatively low humidity areas (Kobayashi et al., 2007). The main step for successful propagation by cuttings is the formation of adventitious roots. This process is influenced by many factors such as the nutritional and hormonal status of the mother plant, cutting type, propagation date, rooting media, presence of leaves on the cutting, exogenous application of auxins and biostimulants, carbohydrates, phenols, anatomical structure of the cutting, light and other factors (Hartmann et al., 2014).

Exogenous application of auxins is one of the most commonly used methods to stimulate adventitious root formation on cuttings (Sokhuma et al., 2018). Treatment of cuttings with auxins results in earlier rooting, more roots, increased percentage and uniformity of rooting (Lima et al., 2019). IBA is the most widely used among the root promoting auxin compounds because it is nontoxic to plants over a wide concentration range and effective over a wide range of species (Hartmann et al., 2014). Application of auxins by themselves or in combination with other substances is commonly used to increase adventitious root formation on cuttings (Mohamed et al., 2014; Ibironke, 2016). Alternative plant growth regulators are natural materials that possess the ability to stimulate the rooting of cuttings; they are suitable substitutes to the synthetic plant growth substances such as auxins, cytokinins and gibberellins which are essential and popular rooting hormones. Examples of alternative growth regulators used are plant growth promoting rhizobacteria (PGPR), seaweed extract, coconut water and moringa leaf extract (Dunsin et al., 2016; Gad and Ibrahim, 2018; Sarmast et al., 2019).

The stimulation of adventitious root formation using PGPR such as Agrobacterium, Bacillus, Pseudomonas and
Azospirillum currently represent an effective method for vegetative propagation of plants (Abdel-Rahman and El-Naggar, 2014; Sarmast et al., 2019). Agrobacterium rhizogenes is one of the PGPR which have recently been used to stimulate adventitious root formation. A. rhizogenes, the causative agent of hair root syndrome, is a common soil organism capable of penetrating plants through wounds and causing proliferation of roots and has been used to enhance adventitious root formation in lavender (Kasem and Abd El-Baset, 2014) and juniper (Sarmast et al., 2019). Seaweed extract was recently used to stimulate root formation on cuttings probably due to the fact that it contains natural growth regulators such as cytokinin-similarities and auxins such as IAA, betanine and IBA as well as amino acids, vitamins, enzymes, sugars, antioxidants and nutrients (Craigie, 2011; Pacholczak and Pietkiewicz, 2014). The earlier tests of seaweed extract in propagation of woody plants look promising (Pacholczak et al., 2016). On the other hand, coconut water is traditionally used as a growth supplement in plant tissue culture. The wide applications of coconut water can be justified by its unique chemical composition of sugars, vitamins, minerals, amino acids, phenols and phytohormones such as gibberellins, auxins (IAA) and cytokinins (Agele et al., 2010; Kurepin et al., 2014). Since, coconut water is a rich in phytohormones and nutrients there is a possibility it can be used to improve adventitious root formation (Ibironke, 2016; Dada et al., 2019).

Therefore, the present research aimed to investigate the impact of IBA with or without growth biostimulants (A. rhizogenes, seaweed and coconut water extracts) on rooting percentage, root and vegetative growth characteristics of different cutting types of $C$. erectus.

\section{MATERIALS AND METHODS}

The current investigation was conducted at the Floriculture Farm, Faculty of Agriculture, Assiut University, Egypt, during 
2017 and 2018 seasons to study the influence of IBA and some biostimulants on rooting, root and growth characteristics of different types of Conocarpus erectus L. cuttings.

On March $1^{\text {st }}$ of 2017 and 2018 seasons, three cutting types (tip, middle and basal) were prepared from one-year-old branches of $C$. erectus. These cuttings had uniform length (15 cm long), the mean thicknesses were $0.5,0.8$ and $1.1 \mathrm{~cm}$ for the terminal, middle and basal cuttings in both seasons, respectively. The cuttings were planted in plastic pots of $20 \mathrm{~cm}$ diameter filled with a mixture of peat moss and perlite $(1: 1 \mathrm{in} \mathrm{v} / \mathrm{v})$ (Abdel-Rahman and El-Naggar, 2014). Physical and chemical properties of the rooting substrate used were done according to the methods described by Jackson (1973) as shown in Table (1). The experiment was done under saran house and covered by tightly polyethylene film to maintain high relative humidity.

Treatments were laid out as a $12 \times 3$ factorial arranged in a split-plot design. Twelve IBA and biostimulants treatments were assigned to the main plots; control (received only water), 100 ppm IBA (soaking for 20 hours), Agrobacterium rhizogenes (drench), 100 ppm IBA $+A$. rhizogenes (drench), seaweed extract (spray), 100 ppm IBA + seaweed extract (spray), seaweed extract (drench), 100 ppm IBA + seaweed extract (drench), coconut water (soaking for 3 minutes), 100 ppm IBA + coconut water (soaking for 3 minutes), coconut water (soaking for 1 hour) and 100 ppm IBA + coconut water (soaking for 1 hour). The sub-plots comprehended three types of cuttings (tip, middle and basal). Each experimental unit contained 20 cuttings
(10 cuttings/pot) replicated four times.

A solution of IBA was used at the concentration of $100 \mathrm{ppm}$ for soaking 2-3 cm of cutting bases for 20 hours. For Agrobacterium rhizogenes, an active strain of Agrobacterium rhizogenes $\left(10^{8} \mathrm{CFU} / \mathrm{ml}\right)$ was obtained from the Unit of Biofertilizers, Fac. Agric., Ain Shams Univ., Egypt. The rooting substrate was inoculated with bacterial suspension prepared of $A$. rhizogenes at a rate of $10 \mathrm{ml} /$ pot before sticking cuttings. On the other hand, the used seaweed extract (Tera) was obtained from CHEMA Company. It contains minerals (Fe, $\mathrm{Zn}, \mathrm{Cu}, \mathrm{Mn}, \mathrm{B}$ and $\mathrm{Mo}$ ), vitamins, enzymes, amino acids, sugars and plant hormones (auxins, cytokinins and gibberellins). Seaweed extract was added as a foliar spray or drench into the rooting substrate at $3 \mathrm{ml} / \mathrm{l}$, which was applied at a rate of $10 \mathrm{ml} / \mathrm{pot}$ when used as drench. All used seaweed treatments were applied at three times (at the beginning of planting, 5 and 10 days after planting). Meanwhile, coconut (Cocos nucifera L.) water was taken from ripe coconut fruits. The basal portions $(2-3 \mathrm{~cm}$ long) of cuttings were dipped in coconut water for the duration of either 3 minutes or 1 hour, just before sticking of cuttings into the rooting substrate.

Three months after planting, cuttings were dug up and cleaned (Abdel-Rahman and El-Naggar, 2014). Data were recorded on rooting percentage, number of roots, root length, stem length, number of branches and leaves per rooted cutting. Also, 1.5-2.0 centimeter of each sample of the bases of cutting were taken and dried for determination of total carbohydrates and phenols content. Total carbohydrate was

Table 1. Some physical and chemical analysis of the rooting substrate used at the beginning of the experiment (average of 2017 and 2018 seasons).

\begin{tabular}{|c|c|c|c|c|c|c|c|c|c|c|c|}
\hline \multirow{3}{*}{$\begin{array}{l}\text { Rooting } \\
\text { substrate }\end{array}$} & \multicolumn{7}{|c|}{ Soluble ions meq/100 g substrate ${ }^{*}$} & \multirow{3}{*}{$\begin{array}{l}\text { Soluble K } \\
\text { mg/100 g } \\
\text { substrate }\end{array}$} & \multirow{3}{*}{$\mathbf{p H}^{* *}$} & \multirow{3}{*}{$\begin{array}{l}E^{* * *} \\
\text { dS } \mathbf{m}^{-1}\end{array}$} & \multirow{3}{*}{$\begin{array}{c}\text { Organic } \\
\text { matter } \\
\%\end{array}$} \\
\hline & & Cati & ons & & & Anions & & & & & \\
\hline & $\mathbf{C a}^{2+}$ & $\mathbf{M g}^{2+}$ & $\mathbf{N a}^{+}$ & $\mathbf{K}^{+}$ & $\mathrm{HCO}_{3}^{-}$ & $\mathrm{Cl}^{-}$ & $\mathrm{SO}_{4}=$ & & & & \\
\hline $\begin{array}{c}\text { Peat + Perlite } \\
\text { (1:1 in v/v) }\end{array}$ & 2.89 & 2.16 & 5.98 & 0.009 & 2.54 & 6.75 & 1.73 & 0.301 & 5.74 & 0.92 & 28.94 \\
\hline
\end{tabular}

* Each value represents the means of 3 replicates; ** Soil-water suspension (1:5); *** Soil-water extract $(1: 5)$. 


\section{S.S.A. Abdel-Rahman et al.}

estimated colorimeterically using anthrone sulphuric acid method described by Fales (1951). The total phenols content was estimated colorimeterically by Folin ciocalteau reagent (FCR) method (Vasco et al., 2008).

Endogenous hormones of IAA, GA and ABA in tissues of fresh cutting bases were isolated by extraction with volatile organic solvents, and quantified according to Zhang et al. (1998) using $\mathrm{C}_{18}$ reversed-phase high performance liquid chromatography (RPHPLC) column. It was isocratically eluted at

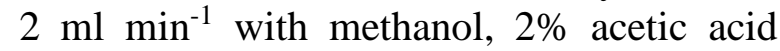
and $\mathrm{H}_{2} \mathrm{O}$ (40:20:20) as mobile phases, detection was with an absorbance monitor operating at $254 \mathrm{~nm}$.

For anatomical structure of cuttings, stem segments of $1.5 \mathrm{~cm}$ long were taken of cutting bases after 3 months from propagation and fixed in formalin: alcohol: glacial acetic acid (1:18:1 by volume) using $70 \%(\mathrm{v} / \mathrm{v})$ ethanol in water in the fixative and for storage after a minimum fixation of three days according to Amissah et al. (2008), then transverse sections were cut by sliding microtome with thickness of 6-9 microns. The double stain of safranin-light green was used by clearing in xylol mounted in DPX according to O'Brien and McCully (1981). Transverse sections were photographed using a five-megapixel camera attached to an optical microscope under the control of a computer. Selections of transverse sections were based on section quality and clarity of the recorded images.

Data obtained were statistically analyzed using ANOVA test according to Snedecor and Cochran (1973) and the means were compared using least significant difference (LSD) test according to Gomez and Gomez (1984).

\section{RESULTS AND DISCUSSION}

\section{Rooting percentage:}

Data presented in Table (2) show that the rooting percentage of $C$. erectus cuttings was significantly increased by IBA with or without biostimulants compared to the untreated cuttings in both seasons. Overall, the individual treatments of seaweed extract and coconut water were more effective in increasing the rooting percentage than IBA or $A$. rhizogenes alone. These findings are in agreement with those reported by Kasem and Abd El-Baset(2014), Pacholczak et al. (2016), Massoud et al. (2017), Sarmast et al. (2019), Ibironke (2019) and Dada et al. (2019), who revealed that treating cuttings with biostimulants enhanced the rooting percentage compared to untreated or IBAtreated cuttings. On the other hand, application of seaweed extract as drench surpassed those of seaweed extract treatments as spray. Also, treating cuttings with coconut water for 1 hour was better than coconut water for $3 \mathrm{~min}$. Many previous reports showed that the effect of biostimulants on rooting, plant growth and development vary with the concentration and application method. Pacholczak et al. (2016) found that rooting percentage of Physocarpus opulifolius cuttings increased linearly according to the seaweed extract concentrations compared to control or IBA. According to Ogunwa (2011), the dipping duration of cuttings (5 and 10 minutes, 1, 2, 3,6 and 10 hours) in coconut water had significant effects on the rooting ability of Bougainvillea spectabilis and B. glabra cuttings. The best rooting performance was obtained from $B$. spectabilis cuttings dipped in coconut water for 1 hour, while B. glabra cuttings had no roots.

Concerning the combined treatments of IBA with biostimulants, it was found that application of IBA with either A. rhizogenes, seaweed extract or coconut water increased the effectiveness of biostimulants in promoting the rooting on cuttings compared to the individual treatments. The maximum rooting percentage $(51.3 \%)$ was obtained from the combined treatment of IBA + coconut water for 1 hour, followed by IBA + seaweed extract as drench $(45.4 \%)$ as average of both seasons. The increment in rooting percentages reached $310.4 \%$ for IBA + coconut water for 1 hour and 263.2\% for 
Table 2. Rooting percentage of Conocarpus erectus L. cuttings as affected by IBA, biostimulants and cutting types after 3 months from planting during 2017 and 2018 seasons.

\begin{tabular}{lcccccccc}
\hline \multicolumn{1}{c}{ Treatments } & \multicolumn{9}{c}{ First season (2017) } & \multicolumn{3}{c}{ Cutting types } \\
\multicolumn{1}{c}{} & Tip & Middle & Basal & Mean & Tip & Middle & Basal & Mean \\
\hline Control & 32.5 & 5.0 & 2.5 & 13.3 & 27.5 & 5.0 & 2.5 & 11.7 \\
IBA & 60.0 & 10.0 & 7.5 & 25.8 & 52.5 & 15.0 & 10.0 & 25.8 \\
A. rhizogenes & 52.5 & 10.0 & 7.5 & 23.3 & 42.5 & 15.0 & 10.0 & 22.5 \\
IBA + A. rhizogenes & 70.0 & 12.5 & 10.0 & 30.8 & 65.0 & 17.5 & 12.5 & 31.7 \\
Seaweed (spray) & 82.5 & 10.0 & 10.0 & 34.2 & 55.0 & 15.0 & 12.5 & 27.5 \\
IBA+ seaweed (spray) & 90.0 & 20.0 & 10.0 & 40.0 & 70.0 & 22.5 & 17.5 & 36.7 \\
Seaweed (drench) & 87.5 & 15.0 & 10.0 & 37.5 & 70.0 & 22.5 & 17.5 & 36.7 \\
IBA + seaweed (drench) & 92.5 & 25.0 & 20.0 & 45.8 & 80.0 & 30.0 & 25.0 & 45.0 \\
Coconut water 3 min & 85.0 & 10.0 & 10.0 & 35.0 & 60.0 & 12.5 & 17.5 & 30.0 \\
IBA + coconut water 3 min & 87.5 & 20.0 & 10.0 & 39.2 & 70.0 & 20.0 & 20.0 & 36.7 \\
Coconut water 1 h & 97.5 & 20.0 & 10.0 & 42.5 & 85.0 & 22.5 & 17.5 & 41.7 \\
IBA + coconut water 1 h & 100.0 & 30.0 & 12.5 & 47.5 & 87.5 & 45.0 & 32.5 & 55.0 \\
Mean & 78.1 & 15.6 & 10.0 & & 63.8 & 20.2 & 16.3 & \\
LSD at 0.05 & & & & & & & & \\
Treatments & & 4.64 & & & & 4.35 & & \\
Cutting types & & 2.45 & & & & 2.22 & & \\
Interaction & & 8.47 & & & & 7.67 & & \\
\hline
\end{tabular}

IBA + seaweed extract as drench over the control as average of both seasons. These results are in harmony with the findings of Sarmast et al. (2012), Pacholczak et al. (2012) and Setiawati et al. (2018), who reported that rooting cuttings treated with either A. rhizogenes, seaweed extract or coconut water can be further improved by synthetic auxin application, which accelerated and increased adventitious root formation in comparison with the treatment without synthetic auxin. Therefore, the exogenous supply of IBA might augment the natural auxin produced as a result of the biostimulants application (Liu et al., 2002). According to Hatta et al. (1996) and Liu et al. (2002), A. rhizogenes has the ability to stimulate rooting of cuttings through the endogenous auxin production (IAA) and/or an increase in the sensitivity of the transformed plant cells to auxin. The beneficial effects of seaweed extract and coconut water on increasing the rooting percentage of $C$. erectus cuttings may be attributed to the presence of auxins and tryptophan (auxin-precursor), sugars, amino acids, vitamins, macro and micronutrients like $\mathrm{Zn}$ and $\mathrm{B}$ in the seaweed extract and coconut water which are largely recognized as important tools to improve adventitious root formation in stem cuttings (Agele et al., 2010; Craigie, 2011; Ibironke, 2016).

Regarding the effect of cutting type, it was noticed that cutting position on the branch significantly affected rooting percentage of $C$. erectus cuttings (Table, 2). Maximum rooting percentage $(71.0 \%)$ was obtained from the tip cuttings compared to the middle and basal ones (17.9 and 13.2\%, respectively). The current findings are similar to those reported by Al-Tohaty et al. (2014), Mohamed et al. (2014), Al-Dulaimy (2016) on Conocarpus spp. and Tilahun et al. (2019) on Araucaria heterophylla, where cuttings from the upper part of the branches rooted better than the lower ones. The better rooting of $C$. erectus tip cuttings may be explained by possibility of higher concentration of endogenous root promoting substances arising in the terminal bud. There is also less differentiation in the tip cuttings 


\section{S.S.A. Abdel-Rahman et al.}

with more cells capable of becoming meristematic (Hartmann et al., 2014). According to Trobec et al. (2005), the low rooting rate of basal cuttings was probably due to higher lignification rate of the basal tissue which can represent a mechanical barrier for root emergence.

The interaction effect between IBA, biostimulants and cutting types on rooting percentage was significant in both seasons (Table, 2). Maximum rooting percentage (93.8\%) resulted from tip cuttings treated with IBA + coconut water for 1 hour, followed by coconut water for 1 hour (91.3\%) and IBA + seaweed extract as drench (86.3\%). On the contrary, the minimum rooting percentage was recorded with untreated basal cuttings (2.5\%). These results are in parallel to those obtained by Mohamed et al. (2014) and Massoud et al. (2017), showed that treating tip cuttings with IBA and/or biostimulants led to increase rooting percentage comparing with the untreated cuttings for Conocarpus erectus and Rosmarinus officinalis, respectively.

\section{Root and shoot characteristics:}

As shown in Tables (3, 4, 5, 6 and 7), treating cuttings of $C$. erectus with IBA and/or biostimulants significantly enhanced root and shoot characteristics comparing with the untreated cuttings during both seasons. Using either seaweed extract or coconut water was superior to A. rhizogenes or IBA alone. Besides, combined treatments of IBA with biostimulants were more effective on improving root and shoot characteristics than the individual ones. Generally, application of IBA combined with coconut water for 1 hour led to the highest root number (12.3), root length $(16.7 \mathrm{~cm})$, stem length $(24.0 \mathrm{~cm})$, branch number (2.2) and leaf number (19.4) per rooted cutting, followed by IBA + seaweed extract as drench (10.9, $15.3 \mathrm{~cm}, 20.5 \mathrm{~cm}, 2.0$ and 16.3 , respectively) as average of both seasons. Conversely, untreated cuttings recorded the lowest values of root number, root length, stem length, branch number and leaf number $(1.2,1.6 \mathrm{~cm}, 7.1 \mathrm{~cm}, 0.6$ and
2.8, respectively) per rooted cutting. The enhancing effects of IBA, A. rhizogenes, seaweed extract and coconut water on the root and vegetative growth characteristics obtained in the present study were also found by Falasca et al. (2000), Pacholczak et al. (2012), Dada et al. (2019) and Sarmast et al. (2019). The increment in root characteristics of $C$. erectus rooted cuttings may be due to the role of auxins (synthetic IBA and natural IAA produced by $A$. rhizogenes or present in seaweed extract and coconut water) in promoting adventitious root development of stem cuttings, through their ability to promote the initiation of root primodia, vascular cambial cells and enhance transport of carbohydrates and rooting co-factors to cuttings' bases as well as accelerate root formation and increase root number and quality per cutting (Zengibal and Özcan, 2006; Hartmann et al., 2014). In addition, seaweed extract and coconut water contain cytokinins, gibberellins and promoting growth substances which helps to stimulate the root growth (Craigie, 2011; Yong et al., 2013). In this regard, Agele et al. (2010) reported that the active compounds present in seaweed extract and coconut water may affect intensification of the synthesis and activity of the natural hormones, facilitation of absorption of nutrients and stimulation of root development. Furthermore, indirect stimulation of root growth may also occur via enhancement of associated soil microorganisms by seaweed extracts (Calvo et al., 2014).

On the other hand, the best shoot characteristics of $C$. erectus cuttings treated with IBA and/or biostimulants may be due to the effective role of auxins on cell division and enlargement; this leads to increase the vegetative growth (Gollan and Wright, 2006). Besides, the presence of many active constituents in the seaweed extract and coconut water which play an important role in improving cell division and the biosynthesis of organic foods (Strick et al., 1997). Furthermore, the increment in shoot characteristics may be attributed to better rooting performance allowing rooted cuttings 
Table 3. Number of roots per rooted cutting of Conocarpus erectus as affected by IBA, biostimulants and cutting types after 3 months from planting during 2017 and 2018 seasons.

\begin{tabular}{lcccccccc}
\hline \multicolumn{1}{c}{ Treatments } & \multicolumn{7}{c}{ First season (2017) } & \multicolumn{3}{c}{ Cutting types } \\
\multicolumn{1}{c}{ Second season (2018) } \\
& Tip & Middle & Basal & Mean & Tip & Middle & Basal & Mean \\
\hline Control & 2.3 & 1.0 & 0.8 & 1.4 & 1.8 & 0.8 & 0.5 & 1.0 \\
IBA & 7.6 & 5.3 & 3.3 & 5.4 & 6.1 & 3.7 & 3.3 & 4.4 \\
A. rhizogenes & 8.2 & 4.0 & 2.0 & 4.7 & 7.5 & 3.9 & 1.6 & 4.3 \\
IBA + A. rhizogenes & 10.0 & 5.3 & 5.0 & 6.8 & 9.8 & 5.6 & 4.3 & 6.6 \\
Seaweed (spray) & 11.6 & 5.3 & 4.3 & 7.1 & 10.3 & 5.5 & 3.9 & 6.6 \\
IBA+ seaweed (spray) & 12.3 & 7.8 & 6.5 & 8.9 & 11.4 & 6.9 & 5.8 & 8.0 \\
Seaweed (drench) & 13.6 & 8.0 & 7.0 & 9.5 & 12.3 & 7.0 & 6.3 & 8.5 \\
IBA + seaweed (drench) & 14.3 & 11.3 & 7.9 & 11.2 & 13.8 & 10.8 & 7.3 & 10.6 \\
Coconut water 3 min & 12.3 & 5.5 & 4.8 & 7.5 & 11.2 & 4.9 & 4.4 & 6.8 \\
IBA + coconut water 3 min & 13.1 & 7.5 & 7.0 & 9.2 & 12.6 & 6.9 & 5.6 & 8.4 \\
Coconut water 1 h & 18.3 & 7.6 & 6.8 & 10.9 & 14.8 & 6.5 & 5.8 & 9.0 \\
IBA + coconut water 1 h & 20.1 & 12.0 & 8.3 & 13.5 & 15.1 & 10.4 & 7.8 & 11.1 \\
Mean & 12.0 & 6.7 & 5.3 & & 10.6 & 6.1 & 4.7 & \\
LSD at 0.05 & & & & & & & & \\
Treatments & & 0.97 & & & & 1.04 & & \\
Cutting types & & 0.43 & & & & 0.50 & & \\
Interaction & 1.48 & & & & 1.73 & & \\
\hline
\end{tabular}

Table 4. Root length (cm) of Conocarpus erectus cutting as affected by IBA, biostimulants and cutting types after 3 months from planting during 2017 and 2018 seasons.

\begin{tabular}{lcccccccc}
\hline \multicolumn{1}{c}{ Treatments } & \multicolumn{7}{c}{ First season (2017) } & \multicolumn{3}{c}{ Cutting types } \\
\multicolumn{1}{c}{ Tip } & Middle & Basal & Mean & Tip & Middle & Basal & Mean \\
\hline Control & 3.3 & 1.3 & 0.3 & 1.6 & 3.1 & 1.0 & 0.3 & 1.5 \\
IBA & 12.5 & 6.4 & 2.6 & 7.2 & 11.8 & 5.3 & 2.1 & 6.4 \\
A. rhizogenes & 12.3 & 4.6 & 1.9 & 6.3 & 11.4 & 3.1 & 1.1 & 5.2 \\
IBA + A. rhizogenes & 16.1 & 8.9 & 4.8 & 9.9 & 15.5 & 7.3 & 4.6 & 9.1 \\
Seaweed (spray) & 14.0 & 5.6 & 3.6 & 7.7 & 13.0 & 4.8 & 2.9 & 6.9 \\
IBA+ seaweed (spray) & 17.5 & 12.6 & 9.0 & 13.0 & 16.0 & 11.9 & 8.4 & 12.1 \\
Seaweed (drench) & 17.8 & 11.5 & 8.4 & 12.6 & 16.5 & 10.7 & 7.1 & 11.4 \\
IBA + seaweed (drench) & 24.9 & 14.5 & 9.5 & 16.3 & 22.3 & 12.8 & 7.8 & 14.3 \\
Coconut water 3 min & 17.5 & 10.0 & 6.5 & 11.3 & 15.8 & 7.9 & 5.9 & 9.9 \\
IBA + coconut water 3 min & 18.2 & 12.6 & 9.0 & 13.3 & 16.5 & 10.5 & 6.5 & 11.2 \\
Coconut water 1 h & 21.1 & 13.1 & 9.1 & 14.4 & 19.1 & 11.0 & 7.9 & 12.7 \\
IBA + coconut water 1 h & 27.5 & 15.5 & 10.4 & 17.8 & 24.0 & 12.9 & 9.5 & 15.5 \\
Mean & 16.9 & 9.7 & 6.3 & & 15.4 & 8.3 & 5.3 & \\
LSD at 0.05 & & & & & & & & \\
Treatments & & 0.87 & & & & 1.23 & & \\
Cutting types & & 0.55 & & & & 0.55 & & \\
Interaction & & 1.89 & & & & 1.91 & & \\
\hline
\end{tabular}


Table 5. Mean stem length (cm) of Conocarpus erectus as affected by IBA, biostimulants and cutting types after 3 months from planting during the 2017 and 2018 seasons.

\begin{tabular}{lcccccccc}
\hline \multicolumn{1}{c}{ Treatments } & \multicolumn{9}{c}{ First season (2017) } & \multicolumn{3}{c}{ Cutting types } & \multicolumn{3}{c}{ Second season (2018) } \\
& Tip & Middle & Basal & Mean & Tip & Middle & Basal & Mean \\
\hline Control & 13.2 & 5.0 & 3.8 & 7.3 & 11.0 & 6.3 & 3.0 & 6.8 \\
IBA & 21.3 & 15.8 & 7.5 & 14.9 & 16.2 & 13.9 & 11.4 & 13.8 \\
A. rhizogenes & 20.8 & 13.3 & 8.8 & 14.3 & 13.4 & 11.0 & 11.4 & 11.9 \\
IBA + A. rhizogenes & 21.6 & 18.5 & 10.8 & 17.0 & 17.4 & 14.9 & 12.3 & 14.9 \\
Seaweed (spray) & 21.9 & 17.4 & 10.0 & 16.4 & 17.4 & 14.3 & 11.4 & 14.4 \\
IBA+ seaweed (spray) & 21.6 & 21.1 & 16.3 & 19.7 & 20.3 & 19.0 & 14.2 & 17.8 \\
Seaweed (drench) & 21.8 & 19.3 & 13.6 & 18.2 & 19.6 & 16.3 & 14.7 & 16.9 \\
IBA + seaweed (drench) & 25.3 & 22.3 & 17.1 & 21.6 & 22.4 & 19.2 & 16.5 & 19.4 \\
Coconut water 3 min & 22.8 & 18.6 & 11.9 & 17.8 & 20.3 & 16.1 & 12.6 & 16.3 \\
IBA + coconut water 3 min & 23.2 & 19.9 & 14.6 & 19.2 & 21.8 & 16.3 & 13.8 & 17.3 \\
Coconut water 1 h & 26.6 & 18.9 & 16.1 & 20.5 & 24.7 & 18.7 & 14.7 & 19.4 \\
IBA + coconut water 1 h & 30.5 & 23.2 & 19.4 & 24.4 & 28.4 & 22.8 & 19.5 & 23.6 \\
Mean & 22.6 & 17.8 & 12.5 & & 19.4 & 15.7 & 13.0 \\
LSD at 0.05 & & & & & & & &
\end{tabular}

Table 6. Mean number of branches per plant of Conocarpus erectus as affected by IBA, biostimulants and cutting types after 3 months from planting during 2017 and 2018 seasons.

\begin{tabular}{|c|c|c|c|c|c|c|c|c|}
\hline \multirow{3}{*}{ Treatments } & \multicolumn{8}{|c|}{ Cutting types } \\
\hline & \multicolumn{4}{|c|}{ First season (2017) } & \multicolumn{4}{|c|}{ Second season (2018) } \\
\hline & Tip & Middle & Basal & Mean & Tip & Middle & Basal & Mean \\
\hline Control & 1.00 & 0.50 & 0.25 & 0.58 & 1.00 & 0.50 & 0.25 & 0.58 \\
\hline IBA & 1.28 & 1.00 & 1.00 & 1.09 & 1.26 & 1.25 & 1.25 & 1.25 \\
\hline A. rhizogenes & 1.28 & 1.00 & 0.75 & 1.01 & 1.05 & 1.00 & 1.00 & 1.02 \\
\hline IBA + A. rhizogenes & 1.53 & 1.38 & 1.50 & 1.47 & 1.36 & 1.38 & 1.25 & 1.33 \\
\hline Seaweed (spray) & 1.33 & 1.50 & 1.00 & 1.28 & 1.53 & 1.50 & 1.00 & 1.34 \\
\hline IBA+ seaweed (spray) & 1.87 & 1.75 & 1.25 & 1.62 & 1.80 & 1.50 & 1.38 & 1.56 \\
\hline Seaweed (drench) & 2.00 & 1.62 & 1.00 & 1.54 & 1.92 & 1.80 & 1.63 & 1.78 \\
\hline IBA + seaweed (drench) & 2.47 & 1.75 & 1.75 & 1.99 & 2.33 & 2.08 & 1.80 & 2.07 \\
\hline Coconut water $3 \mathrm{~min}$ & 2.10 & 1.50 & 1.00 & 1.53 & 1.80 & 1.75 & 1.50 & 1.68 \\
\hline IBA + coconut water $3 \mathrm{~min}$ & 2.38 & 1.62 & 1.25 & 1.75 & 2.04 & 1.88 & 1.75 & 1.89 \\
\hline Coconut water $1 \mathrm{~h}$ & 2.80 & 1.87 & 1.50 & 2.06 & 2.65 & 1.96 & 1.88 & 2.16 \\
\hline IBA + coconut water $1 \mathrm{~h}$ & 2.73 & 1.92 & 1.50 & 2.05 & 2.75 & 2.05 & 2.05 & 2.28 \\
\hline Mean & 1.90 & 1.45 & 1.15 & & 1.79 & 1.55 & 1.40 & \\
\hline \multicolumn{9}{|l|}{ LSD at 0.05} \\
\hline Treatments & \multicolumn{3}{|c|}{0.32} & \multicolumn{5}{|c|}{0.24} \\
\hline Cutting types & \multicolumn{3}{|c|}{0.16} & \multicolumn{5}{|c|}{0.13} \\
\hline Interaction & \multicolumn{3}{|c|}{ N.S } & \multicolumn{5}{|c|}{ N.S } \\
\hline
\end{tabular}


Table 7. Mean number of leaves per plant of Conocarpus erectus as affected by IBA, biostimulants and cutting types after 3 months from planting during 2017 and 2018 seasons.

\begin{tabular}{lcccccccc}
\hline \multicolumn{1}{c}{ Treatments } & \multicolumn{7}{c}{ First season (2017) } & \multicolumn{3}{c}{ Cutting types } \\
\multicolumn{1}{c}{} & Tip & Middle & Basal & Mean & Tip & Middle & Basal & Mean \\
\hline Control & 5.3 & 1.3 & 0.3 & 2.3 & 5.6 & 2.8 & 1.4 & 3.3 \\
IBA & 11.7 & 8.0 & 5.3 & 8.3 & 11.2 & 9.5 & 6.0 & 8.9 \\
A. rhizogenes & 11.1 & 5.5 & 4.0 & 6.9 & 10.3 & 6.3 & 4.0 & 6.9 \\
IBA + A. rhizogenes & 12.5 & 11.5 & 8.3 & 10.8 & 12.3 & 10.9 & 8.0 & 10.4 \\
Seaweed (spray) & 14.5 & 10.0 & 8.0 & 10.8 & 12.6 & 10.8 & 6.5 & 10.0 \\
IBA+ seaweed (spray) & 13.4 & 15.0 & 12.0 & 13.5 & 16.0 & 13.1 & 11.4 & 13.5 \\
Seaweed (drench) & 13.0 & 13.1 & 10.3 & 12.1 & 13.2 & 12.6 & 11.4 & 12.4 \\
IBA + seaweed (drench) & 21.7 & 15.3 & 13.5 & 16.8 & 21.8 & 13.8 & 11.9 & 15.8 \\
Coconut water 3 min & 16.0 & 12.8 & 9.8 & 12.9 & 16.0 & 11.3 & 9.8 & 12.4 \\
IBA + coconut water 3 min & 20.2 & 13.9 & 11.8 & 15.3 & 19.7 & 13.5 & 11.0 & 14.7 \\
Coconut water 1 h & 24.4 & 14.3 & 12.0 & 16.9 & 23.8 & 13.5 & 11.4 & 16.2 \\
IBA + coconut water 1 h & 29.9 & 16.0 & 14.1 & 20.0 & 27.6 & 15.0 & 13.4 & 18.7 \\
Mean & 16.1 & 11.4 & 9.1 & & 15.8 & 11.1 & 8.9 & \\
LSD at 0.05 & & & & & & & & \\
Treatments & & 1.07 & & & & 1.19 & & \\
Cutting types & & 0.43 & & & & 0.56 & & \\
Interaction & & 1.50 & & & & 1.94 & & \\
\hline
\end{tabular}

to absorb more water and nutrients from rooting substrate, which in turn will contribute to better vegetative growth (Khan et al., 2009).

Regarding the effect of cutting types, it was noticed that propagation of $C$. erectus by tip cuttings produced the best number and length of roots that reflected in improving the quality and growth of shoots compared to cuttings from the middle and basal part of the stem (Tables 3, 4, 5, 6 and 7). These results are in conformity with those of Mohamed et al. (2014), Al-Dulaimy (2016) and Tilahun et al. (2019), who revealed that using tip cuttings resulted in the highest root and vegetative growth measurements of rooted cuttings comparing with the middle and basal ones.

The interaction effect between IBA, biostimulants and cutting types on root number, root length and leaf number per rooted cutting was significant, but this effect was not significant on stem length and branch number in both seasons. The best combination of IBA + coconut water for 1 hour with tip cuttings which recorded the highest rooting percentage (93.8\%) was associated with the marked improvement in root measurements which positively reflected on better vegetative characteristics of rooted cuttings than the other combinations given lower results. Similar results were obtained by Mohamed et al. (2014), Massoud et al. (2017) and Tilahun et al. (2019), who found that the root and shoot measurements were improved by treating tip cuttings with IBA and/or biostimulants compared to untreated cuttings. The increment in root and shoot characteristics may be associated with the balance between endogenous levels of hormones and food materials in cutting tissues (Wróblewska, 2015).

\section{Total carbohydrates (\%) and phenols content:}

Data presented in Table (8 and 9) clearly show that total carbohydrates \% and phenols content in basal part of C. erectus cuttings 
Table 8. Total carbohydrates (\%) in Conocarpus erectus cutting bases as affected by IBA, biostimulants and cutting types after 3 months from planting during 2017 and 2018 seasons.

\begin{tabular}{|c|c|c|c|c|c|c|c|c|}
\hline \multirow{3}{*}{ Treatments } & \multicolumn{8}{|c|}{ Cutting types } \\
\hline & \multicolumn{4}{|c|}{ First season (2017) } & \multicolumn{4}{|c|}{ Second season (2018) } \\
\hline & Tip & Middle & Basal & Mean & Tip & Middle & Basal & Mean \\
\hline Control & 7.8 & 10.3 & 11.5 & 9.9 & 7.0 & 9.4 & 10.7 & 9.0 \\
\hline IBA & 9.7 & 13.9 & 19.6 & 14.4 & 8.8 & 12.1 & 18.2 & 13.0 \\
\hline A. rhizogenes & 8.0 & 11.7 & 15.6 & 11.8 & 8.3 & 10.2 & 14.6 & 11.0 \\
\hline IBA + A. rhizogenes & 12.0 & 14.3 & 22.7 & 16.3 & 10.9 & 13.7 & 20.3 & 15.0 \\
\hline Seaweed (spray) & 11.4 & 14.8 & 20.5 & 15.6 & 10.0 & 14.1 & 18.4 & 14.2 \\
\hline IBA+ seaweed (spray) & 14.9 & 19.5 & 28.3 & 20.9 & 15.3 & 17.6 & 27.2 & 20.0 \\
\hline Seaweed (drench) & 16.4 & 22.4 & 25.8 & 21.5 & 15.8 & 21.2 & 24.5 & 20.5 \\
\hline IBA + seaweed (drench) & 17.7 & 20.8 & 31.3 & 23.3 & 16.3 & 19.9 & 29.9 & 22.1 \\
\hline Coconut water 3 min & 13.0 & 17.0 & 23.9 & 17.9 & 11.0 & 17.1 & 20.4 & 16.1 \\
\hline IBA + coconut water $3 \mathrm{~min}$ & 12.5 & 18.9 & 28.4 & 19.9 & 11.7 & 15.7 & 25.0 & 17.5 \\
\hline Coconut water $1 \mathrm{~h}$ & 16.7 & 21.7 & 30.0 & 22.8 & 14.9 & 19.2 & 28.8 & 21.0 \\
\hline IBA + coconut water $1 \mathrm{~h}$ & 17.7 & 25.4 & 32.9 & 25.3 & 17.2 & 24.8 & 30.6 & 24.2 \\
\hline Mean & 13.2 & 17.5 & 24.2 & & 12.3 & 16.3 & 22.4 & \\
\hline \multicolumn{9}{|l|}{ LSD at 0.05} \\
\hline Treatments & & 1.08 & & & & 1.08 & & \\
\hline Cutting types & & 0.61 & & & & 0.49 & & \\
\hline Interaction & & 2.12 & & & & 1.71 & & \\
\hline
\end{tabular}

Table 9. Total phenols content (mg GEA/g D.Wt.) in C. erectus cutting as affected by IBA, biostimulants and cutting types after 3 months from planting during 2017 and 2018 seasons.

\begin{tabular}{|c|c|c|c|c|c|c|c|c|}
\hline \multirow{3}{*}{ Treatments } & \multicolumn{8}{|c|}{ Cutting types } \\
\hline & \multicolumn{4}{|c|}{ First season (2017) } & \multicolumn{4}{|c|}{ Second season $(2018)$} \\
\hline & Tip & Middle & Basal & Mean & Tip & Middle & Basal & Mean \\
\hline Control & 39.7 & 7.5 & 1.6 & 16.3 & 22.3 & 5.5 & 1.8 & 9.9 \\
\hline IBA & 60.0 & 36.2 & 11.0 & 35.7 & 37.4 & 20.7 & 10.5 & 22.9 \\
\hline A. rhizogenes & 46.3 & 24.6 & 7.5 & 26.1 & 26.8 & 16.1 & 6.0 & 16.3 \\
\hline IBA + A. rhizogenes & 54.5 & 37.7 & 18.2 & 36.8 & 40.6 & 25.7 & 12.6 & 26.3 \\
\hline Seaweed (spray) & 56.6 & 35.8 & 19.6 & 37.3 & 43.6 & 28.0 & 17.1 & 29.6 \\
\hline IBA+ seaweed (spray) & 59.3 & 49.9 & 27.9 & 45.7 & 49.2 & 34.1 & 20.9 & 34.7 \\
\hline Seaweed (drench) & 60.4 & 40.3 & 24.5 & 41.7 & 46.7 & 33.0 & 23.4 & 34.4 \\
\hline IBA + seaweed (drench) & 60.4 & 52.2 & 37.1 & 49.9 & 54.8 & 43.0 & 27.8 & 41.9 \\
\hline Coconut water 3 min & 58.7 & 34.2 & 21.4 & 38.1 & 41.4 & 27.5 & 19.3 & 29.4 \\
\hline IBA + coconut water $3 \mathrm{~min}$ & 61.4 & 50.7 & 29.0 & 47.0 & 49.3 & 37.2 & 25.3 & 37.3 \\
\hline Coconut water 1 h & 64.3 & 41.7 & 28.7 & 44.9 & 51.1 & 30.7 & 21.9 & 34.6 \\
\hline IBA + coconut water $1 \mathrm{~h}$ & 61.8 & 46.1 & 31.1 & 46.3 & 60.3 & 43.0 & 30.3 & 44.5 \\
\hline Mean & 57.0 & 38.1 & 21.5 & & 43.6 & 28.7 & 18.1 & \\
\hline \multicolumn{9}{|l|}{ LSD at 0.05} \\
\hline Treatments & & 3.02 & & & & 1.87 & & \\
\hline Cutting types & & 1.35 & & & & 1.16 & & \\
\hline Interaction & & 4.67 & & & & 4.01 & & \\
\hline
\end{tabular}


was considerably affected by the different treatments of IBA, biostimulants and cutting types. It is obvious that treating cuttings with IBA and/or biostimulants significantly increased the total carbohydrates $\%$ and phenols content compared to untreated cuttings in both seasons. The combined treatments of IBA with biostimulants were more effective on increasing total carbohydrates \% and phenols content than the individual ones. Generally, cuttings treated with IBA + coconut water for 1 hour contained higher levels of total carbohydrates and phenols which led to maximum rooting percentage, root and shoot measurements, followed by the combined treatment of IBA + seaweed extract as drench. These results are in accordance with those reported by Denaxa et al. (2012), Kasem and Abd El-Baset (2014), Izadi et al. (2016) and Pacholczak et al. (2016). They stated that higher levels of total carbohydrates and phenols could stimulate adventitious root formation and improve root development. The positive relationship between rootability and the high contents of carbohydrates and phenols in basal part of $C$. erectus cuttings treated with IBA and/or biostimulants could be attributed to certain evidences supported by the effective role of carbohydrates and phenols as well as synthesis of IAA by A. rhizogenes, seaweed and coconut water in the presence of IBA to exert an effect on the rootability of cuttings. Carbohydrates have been considered to be the principal source of energy and carbon (Fabbri et al., 2004) as well as cell structural materials for the initiation of root primordia (Yoo and Kim, 1996). Carbohydrates concentration in cutting tissues may be influenced by auxins, which can enhance starch hydrolysis and mobilization of carbohydrate from leaves and upper stem towards the rooting zone (Davies, 2004). Arslonov (1979) observed breakdown of carbohydrates during the initial stages of root growth in lemon cuttings and also noted a rise in catalase and peroxidase activities which accompanied by the breakdown of carbohydrates. Besides, sufficient of both carbohydrates and nitrogenous basis works with others in synthesis of the building blocks for nucleic acids (DNA and RNA). These biochemical compounds are the main source in synthesis of proteins as well as carbohydrates and fats metabolism which they are all necessary for normal cell division (Cannon et al., 2002). On the other hand, many researchers (Aslmoshtaghi and Shahsavar, 2010; Izadi et al., 2016) reported that the phenolic compounds act as auxin cofactors in promotion of adventitious root formation. The role of phenolic compounds in adventitious root formation is hypothesized to be in protecting the rootinginducer endogenous auxin IAA from being destructed by peroxidase, which can act as an IAA oxidase (Trobec et al., 2005; De Klerk et al., 2011; Izadi et al., 2016). Accordingly, the increment in polyphenolic compounds as a result of treatment of $C$. erectus cuttings with IBA and/or biostimulants has a direct role in inhibiting auxin oxidation so more auxin is available to induce roots, consequently improve rooting ability as well as root and shoot characteristics (Scagel and Linderman, 1998).

Concerning the effect of cutting types, results obtained in the present study indicated that the contents of total carbohydrates and phenols in cutting tissues of $C$. erectus were considerably affected by cutting portion on the branch (Tables, 7 and 8). Basal cuttings contained higher content of total carbohydrates than tip and middle ones. Meanwhile, the tip cuttings were markedly higher in total phenols content than middle and basal ones, with significant differences in the two seasons. These results are in agreement with those obtained by Haissig (1974), Abdel-Rahman and ElNaggar (2014) and Attia (2016). Reuveni and Adato (1974) found that the change from juvenile to adult is correlated with an increase of carbohydrates in the tissue. However, the obtained results in the present study indicated that the rootability of basal cuttings was not related to their total carbohydrates content. Similar results were 


\section{S.S.A. Abdel-Rahman et al.}

reported by Denaxa et al., (2012) and Attia (2016). For phenols, Haissig (1974) and Trobec et al. (2005) stated that phenols in juvenile tissues of certain plants tend to be higher than their mature forms. More lignified tissues have additionally a higher IAA-oxidase activity (Liu et al., 1998); therefore conditions were even less favorable for root formation of basal cuttings, which evidently could not keep the endogenous IAA concentration on the level of satisfying rooting.

The statistical analysis showed that treatment of basal cuttings with IBA + coconut water for 1 hour gave the maximum total carbohydrates \%, followed by IBA + seaweed extract as drench which was statistically similar to coconut water for 1 hour treatment with the same cutting type. Meanwhile, untreated tip cuttings showed minimum total carbohydrates \%. On the other hand, the tip cuttings treated with IBA + coconut water for 1 hour contained the highest total phenols content, while the untreated basal cuttings recorded the minimum total phenols content in both seasons. The current findings indicate that the effectiveness of auxins for root formation may be related to changes in the levels of internal contents of phenols and carbohydrates in stem cuttings. These were supported by the works of Eklöf et al. (2000). Therefore, the adventitious root formation could be due to influences of auxins interaction with chemicals, growth co-factors or auxins synergists of carbohydrates and phenols compounds.

\section{Promoters and inhibitors:}

HPLC analysis (Fig., 1) of the samples extracted from basal portion root zone of the tip, middle and basal cuttings of $C$. erectus for the control and best treatment of IBA + coconut water for 1 hour which produced the maximum rooting percentage and the best root and shoot characteristics as well as the highest total carbohydrates \% and phenols content, showed that the combined treatment of IBA + coconut water for 1 hour marked the highest endogenous contents of IAA and GA (44.0 and $75.3 \mu \mathrm{g} / \mathrm{g}$ f.w., respectively) but the lowest ABA (0.123 $\mu \mathrm{g} / \mathrm{g}$ f.w.). Whereas, the control treatment showed the lowest content of IAA and GA (21.2 and $29.6 \mu \mathrm{g} / \mathrm{g}$ f.w., respectively) but the highest ABA (0.209 $\mu \mathrm{g} / \mathrm{g}$ f.w.). These results may be due to the role of combined treatment of IBA + coconut water in increasing the contents of IAA and GA at the root zone of $C$. erectus cuttings. Since, coconut water contains phytohormones like auxin (IAA), gibberellins and cytokinins as well as many other active components which further play an important role in plant growth and root formation (Ibironke, 2019; Dada et al., 2019). Besides, exogenous IBA application might have supplemented the endogenous
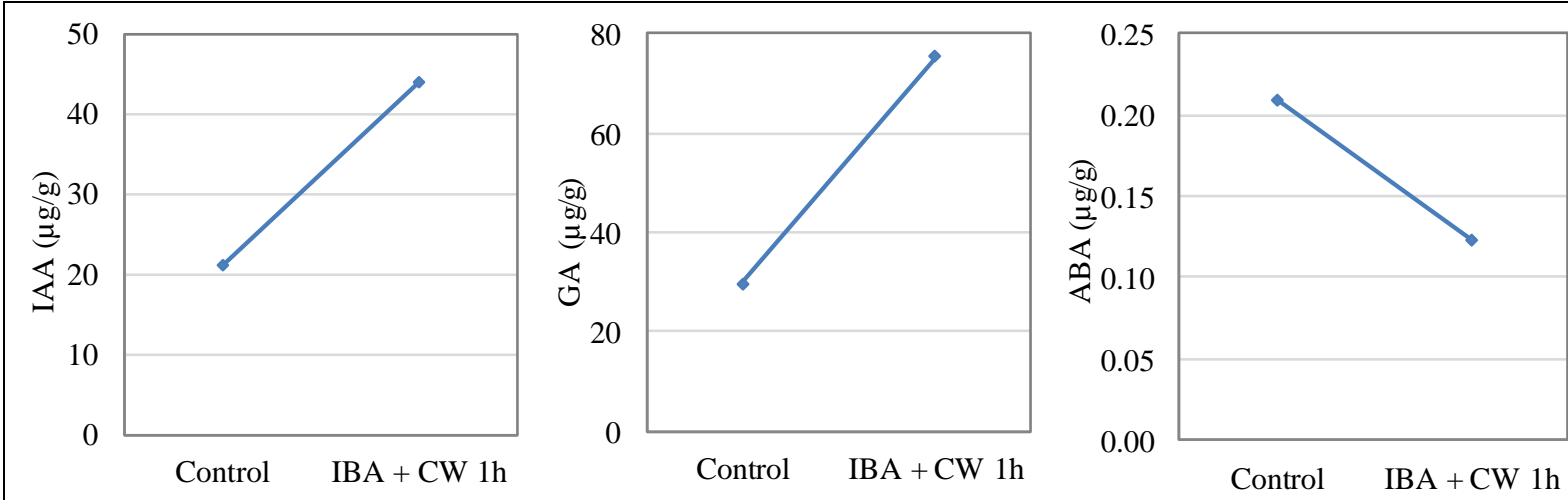

Fig. 1. Reversed-phase high performance liquid chromatography (RP-HPLC) analysis of two samples extracted from root zone of Conocarpus erectus $\mathrm{L}$. cuttings treated with IBA + coconut water for $1 \mathrm{~h}$ and the control. 
auxin ingredient at the base of cuttings. The reason for this might be the acceleration of the root initiation and genesis of root primordia that resulted in increased rooting in treated cuttings (Gaspar and Hofinger, 1988). Auxin plays an effective role in many aspects of root growth, development and differentiation. IAA regulates the development of the primary and lateral roots (Raven et al., 2005), root apical meristem (Jiang and Feldman, 2005), root cap (Ponce et al., 2005) and root vascular differentiation (Aloni, 2004).

On the other hand, gibberellic acid has promotive effects on adventitious root formation as suggested by Petridou and Porlingis (1997) and Hartmann et al. (2014). Abo El-Enien and Omar (2018) stated that there is a positive relationship between the higher rootability of Casimiroa edulis cuttings and high endogenous GA level. GA effect indirectly on adventitious root formation by increasing endogenous auxin through inhibition of IAA oxidase sparing effect and/or stimulation of auxin synthesis (Coleman and Greyson, 1977). Besides, GA have a function in regulating cell division and elongation as well as nucleic acid and protein synthesis (Spaepen et al., 2009). As for abscisic acid (ABA), it is known that ABA generally has inhibitory effects. A negative relationship between root development and endogenous ABA was reported by Kelen and Ozkan (2003) and Hartmann et al. (2014). The role of ABA is critical for wound response and perhaps sink strength establishment, although its negative roles on the cell cycle may inhibit root induction (Da Costa et al., 2013). It was detected an inverse relationship between IAA and ABA contents in the cuttings. Kelen and Ozkan (2003) found a high IAA and low ABA levels in high rooting percentage of grape cuttings, whereas the opposite was observed in low rooting rate cuttings.

As shown in Fig. (2), it is clearly appeared that the tip cuttings of $C$. erectus contained the highest levels of IAA (55.9 $\mu \mathrm{g} / \mathrm{g}$ f.w.) and GA (111.8 $\mu \mathrm{g} / \mathrm{g}$ f.w.) but the lowest ABA level $(0.061 \mu \mathrm{g} / \mathrm{g}$ f.w.). On the contrary, basal cuttings contained the highest ABA level (0.303 $\mu \mathrm{g} / \mathrm{g}$ f.w.) but the lowest levels of IAA (15.1 $\mu \mathrm{g} / \mathrm{g}$ f.w.) and GA (19.7 $\mu \mathrm{g} / \mathrm{g}$ f.w.) compared to the tip and middle ones (Fig. 2). The increment in endogenous IAA content in tip cutting tissues treated with IBA + coconut water for 1 hour may be due to the high contents of phenolic compounds and GA in tip cuttings which have an effective role in protecting the endogenous IAA from being destructed by IAA-oxidase (Coleman and Greyson, 1977; Trobec et al., 2005).

Fig. (3) shows that treating tip cuttings

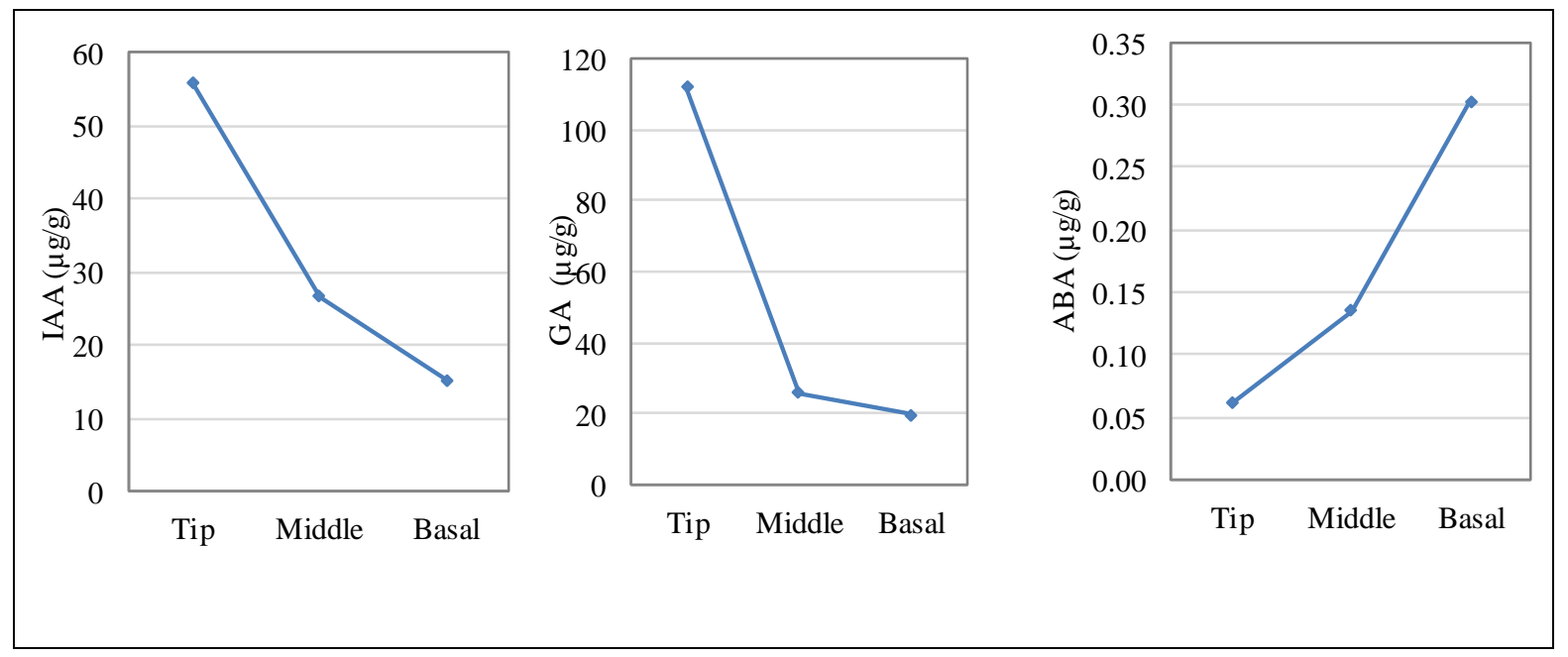

Fig. 2. Effect of cutting types on content of IAA, GA and ABA at root zone of Conocarpus erectus L. cuttings. 


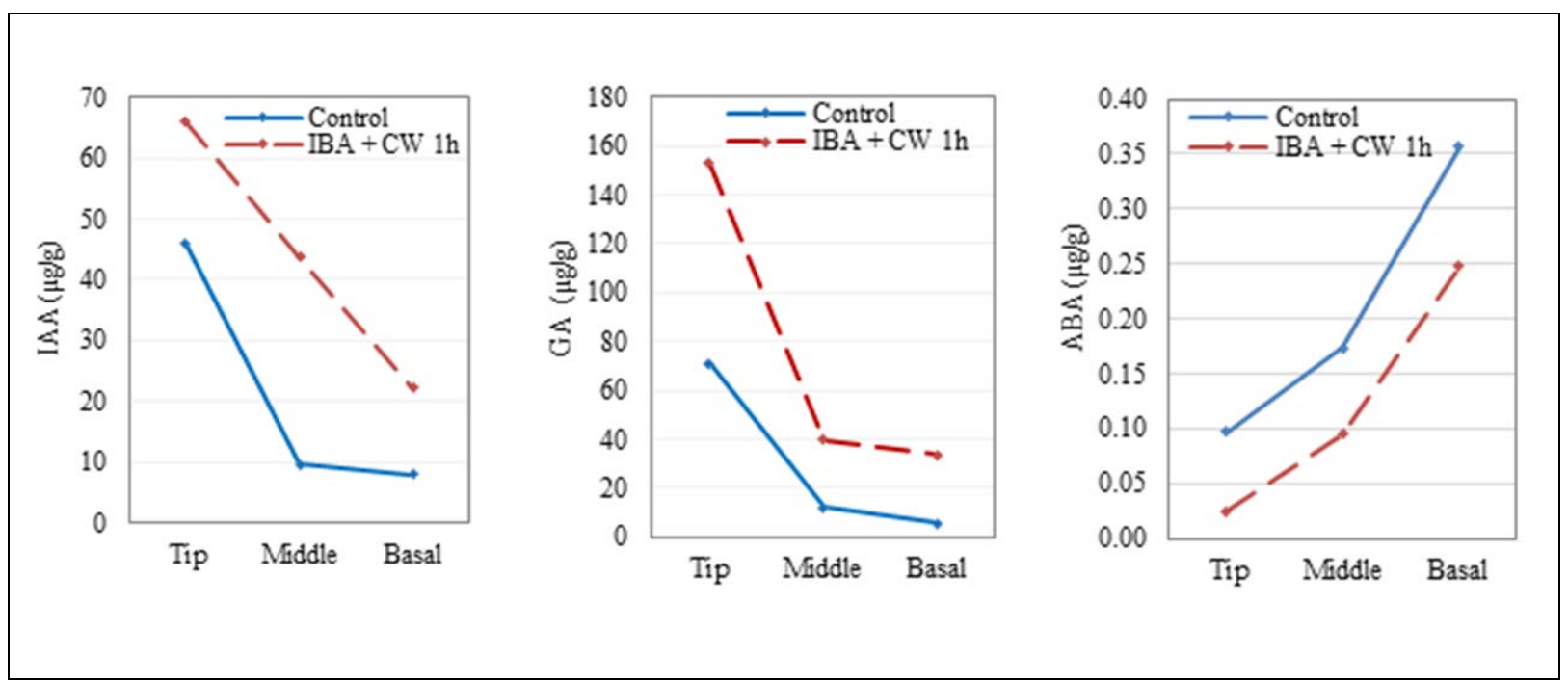

Fig. 3. Content of IAA, GA and ABA at root zone of three cutting types of Conocarpus erectus $\mathrm{L}$. treated with IBA + coconut water for $1 \mathrm{~h}$ and the control.

with IBA + coconut water for 1 hour resulted in the highest endogenous levels of IAA (66.0 $\mu \mathrm{g} / \mathrm{g}$ f.w.) and GA (152.7 $\mu \mathrm{g} / \mathrm{g}$ f.w.), but the lowest ABA level (0.025 $\mu \mathrm{g} / \mathrm{g}$ f.w.). Meanwhile, untreated basal cuttings recorded the lowest levels of IAA $(8.051 \mu \mathrm{g} / \mathrm{g}$ f.w.) and GA (5.8 $\mu \mathrm{g} / \mathrm{g}$ f.w.) as well as the highest ABA level (0.36 $\mu \mathrm{g} / \mathrm{g}$ f.w.). These results indicate that the tip cuttings of $C$. erectus contain high amounts of root promoting substances i.e., phenolic components, IAA and GA as a result of IBA and biostimulants application which explains the better rooting, root and growth characteristics of tip cuttings than middle and basal ones. Similar trends were reported by Singh (2017) and Tilahun et al. (2019).

\section{Anatomical structure of cuttings:}

Transverse sections of the rooting zone of Conocarpus erectus cutting are shown in Figs. (4, A, B, C and D). It was evident from these sections that the stem has a cylindrical shape consisting of the following features from outside to inside; epidermis, cortex, pericycle, vascular bundles, outer secondary phloem, cambium, secondary xylem, primary xylem, inner phloem and pith. The internal tissues of $C$. erectus stem cutting appeared that the lignified sclerenchyma tissue (sclerenchymatous pericycle) is organized as a continuous ring surrounding the outer secondary phloem layer. The continuity of sclerenchyma tissues negatively affects rooting ability, initiation of root primordium and development of $C$. erectus untreated cutting (Fig. 4A).

The obtained results therefore provide indirect evidence of relationship existence between anatomy and rooting ability of cuttings. Treatment of $C$. erectus cuttings with either IBA, IBA + seaweed extract as drench or IBA + coconut water for 1 hour stimulated root initiation, root primordium formation, root elongation, root emergence, growth and development compared to the untreated cuttings (Fig. 4, B, C and D). Transverse sections of the rooting zone showed that the meristematic cells of initial roots continuously divide forming new cells proliferated mainly from vascular cambium and phloem. The substantial cell expansion and proliferation in the cambium and phloem that were enough to cause breaks in the continuous sheath of sclerenchyma tissue and allowing for root primordium to penetrate though phloem and sclerenchyma ring. The new roots had emerged through splits in the epidermis in successful cuttings. By the time of root emergence, fully matured vascular connections had been established between the vascular systems of the adventitious roots and that of the cutting. Roots originated only in proliferative tissue within secondary phloem. In cuttings that did 

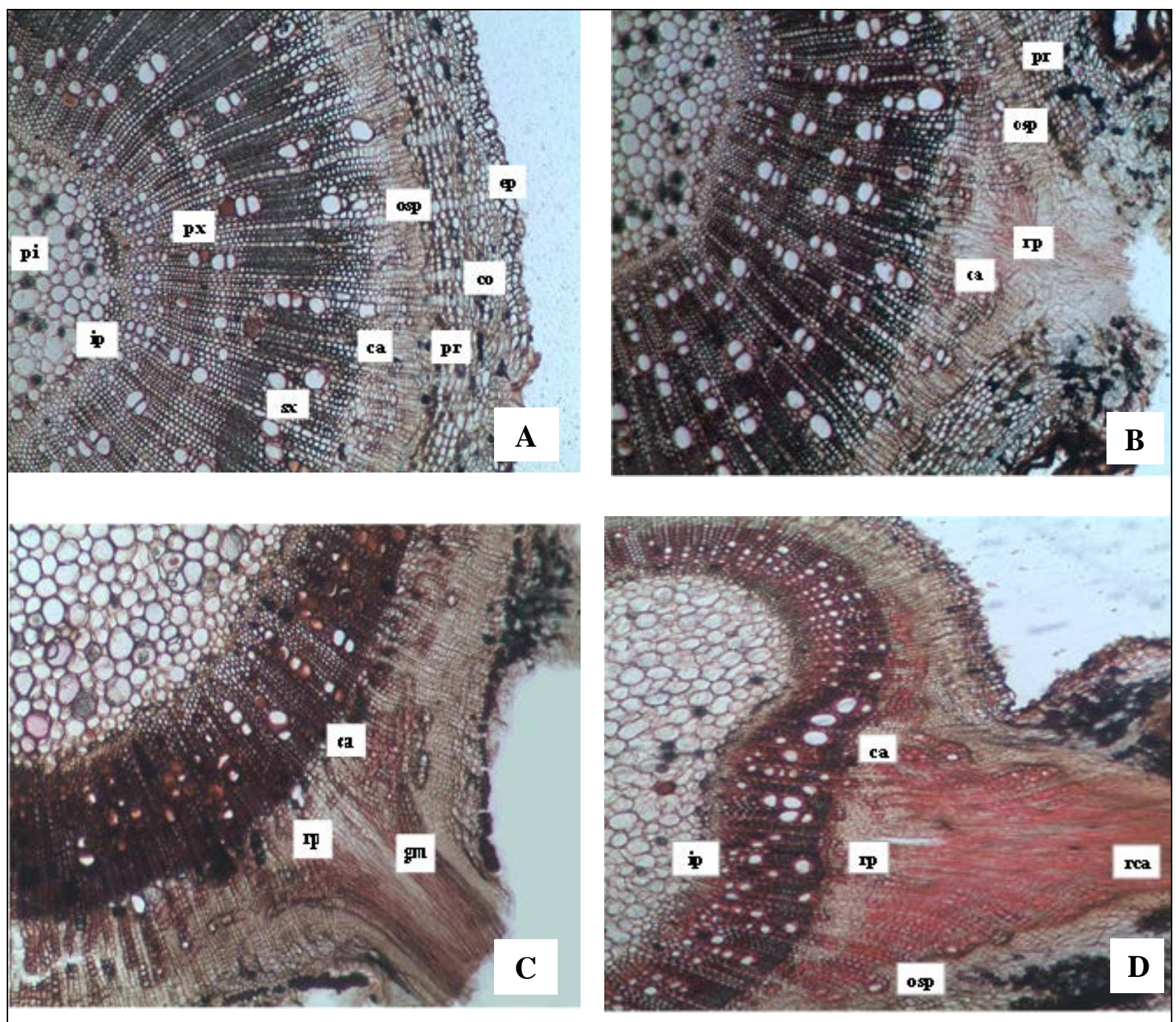

Fig. 4. Transverse sections in the rooting zone of Conocarpus erectus cuttings as affected by different treatments; control (A), IBA (B), IBA + seaweed extract as drench (C) and IBA + coconut water for $1 \mathrm{~h}$ (D) after 3 months from propagation. $\mathrm{X}=$ $200 \mu \mathrm{m}$. ep= epidermis; co= cortex; $\mathbf{p r}=$ pericycle; $\mathbf{o s p}=$ outer secondary phloem; ca $=$ cambium; $\mathbf{s x}=$ secondary $x y l e m ; \mathbf{p x}=$ primary $\mathbf{x y l e m} ; \mathbf{i p}=$ inner phloem; $\mathbf{p i}=$ pith; $r p=$ root primordium; rca= root cap; $\mathbf{g m}=$ ground meristem.

not root, only the first stage of expansion occurred, to a less extent than was observed in cuttings that rooted. Formation of a darkstaining ring of sclerenchyma cells at the periphery of the vascular tissue was evident in C. erectus stem cutting. These observations are similar to those reported by Attia (2016), who stated that rootability of some easy- and difficult-to-root stem cuttings of ornamental plants is regarded to anatomical structures of stem these plants. According to Hartmann et al. (2014), the poor rooting of difficult-to-root cuttings was related to the presence of sclerenchyma ring between the phloem and cortex, which acted as mechanical barriers preventing the emergence of roots, while easily rooted types were characterized by discontinuity of such ring.

On the other hand, several studies declared the positive effects of exogenous auxin application on cell division, cell elongation and certain stages of differentiation during adventitious root formation (Attia, 2016; Hussein, 2018). Auxins application caused considerable cell expansion and proliferation in the cortex, 


\section{S.S.A. Abdel-Rahman et al.}

phloem, and cambium resulting discontinuous sclerenchyma rings, while root primordia were absent in untreated cuttings, which may explain why untreated cuttings are difficult-to-root (El-Nashar, 2008). The higher endogenous IAA level could be related to the activation of the cambium and the formation of cambial derivatives, as auxins promote vascular differentiation (Gaspar et al., 1996). In addition, the active compounds present in the seaweed extract and coconut water may stimulate rhizogenesis by inducing anatomical and morphological changes in plants (Cambri et al., 2008). Accordingly, the higher endogenous IAA level in cutting tissues of C. erectus as a result of IBA and/or biostimulants treatments is directly related to better root initiation, differentiation, elongation and increasing the rooting percentage than the untreated cuttings.

\section{REFERENCES}

Abdel-Rahman, S.S.A. and El-Naggar, A.I. (2014). Promotion of rooting and growth of some types of bougainvilleas cutting by plant growth promoting rhizobacteria (PGPR) and arbuscular mycorrhizal fungi (AMF) in combination with indole-3butyric acid (IBA). Inter. J. Sci. Res., 3(11):97-108.

Abo El-Enien, H.E. and Omar, M.A. (2018). Effect of some growth substances on rooting and endogenous hormones of Casimiroa edulis L. cuttings. Zagazig J. Agric. Res., 45(3):891-904.

Agele, S.O.; Ayankanmi, T.G. and Kikuno, H. (2010). Effects of synthetic hormone substitutes and genotypes on rooting and mini tuber production of vine cuttings obtained from white yam (Dioscorea rotundata Poir). African J. Biotech., 9(30):4714- 4724.

Al-Dulaimy, H.A. (2016). Effect of cutting types on stem and growing media on cuttings rooting and vegetative growth of Conocarpus lancifolius. Al-Kufa Univ. J. Bio., 8(1):98-103.
Aloni, R. (2004). The induction of vascular tissue by auxin. In: Davies P.J.; ed. Plant hormones: Biosynthesis, Signal Transduction, Action! Dordrecht: Kluwer, pp. 471-492.

Al-Tohaty, S.A.; Lateef, A.A. and Abdel Raheem, H.A. (2014). Effect of cuttings type, planting date and treatment of indole butyric acid (IBA) on rooting of cuttings and vegetative growth properties of damas (Conocarpus lancifolius) for summer season. Alforat J. Agric. Sci., 6(2):1-11.

Amissah, J.N.; Paolillo Jr., D.J. and Bassuk, N. (2008). Adventitious root formation in stem cuttings of Quercus bicolor and Quercus macrocarpa and its relationship to stem anatomy. J. Amer. Soc. Hort. Sci., 133(4):479-486.

Arslonov, M.N. (1979). Physiological changes occurring during root formation in lemon cuttings. Uzabekskii Biologicheskii Zhurnal, 5:24-26.

Aslmoshtaghi, E. and Shahsavar, A.R. (2010). Endogenous soluble sugars, starch contents and phenolic compounds in easy- and difficult-to-root olive cuttings. J. Biological and Environmental Sciences, 4:83-86.

Attia, F.A.K.K. (2016). Studies on Rooting and Growth of Dracaena and Cordyline Plants. Ph.D. Thesis, Fac. Agric., Assiut Univ., Egypt, 259 p.

Calvo, P.; Nelson, L. and Kloepper, J.W. (2014). Agricultural uses of plant biostimulants. Plant Soil, 383:3-41.

Cambri, D.; Filippini, L.; Apone, F.; Arciello, S.; Colucci, D. and Portoso, G. (2008). Effect of AminoPlant ${ }^{\circledR}$ on expression of selected genes in Arabidopsis thaliana L. plants. In: Biostimulators in modern agriculture. General Aspects. WieĞ Jutra, Warszawa, pp. 77-82.

Cannon, M.J.; Myszka, D.G.; Bagnate, D.J.; Alpers, D.H.; West, F.G. and Grissom, C.B. (2002). Equilibrium and kinetic 
analyses of the interactions between vitamin B12 binding proteins and colalamins by surface plasman resonance. Anal. Biochem., 305:1-9.

Coleman, W.K. and Greyson, R.I. (1977). Promotion of root initiation by gibberellic acid in leaf discs of tomato (Lycopersicon esculentum) cultured in vitro. New Phytol., 78:47-54.

Craigie, J.S. (2011). Seaweed extract stimuli in plant science and agriculture. J. Appl. Phyco., 23(3):371- 393.

Da Costa, C.T.; de Almeida, M.R.; Ruedell, C.M.; Schwambach, J.; Maraschin, F.S. and Fett-Neto, A.G. (2013). When stress and development go hand in hand: main hormonal controls of adventitious rooting in cuttings. Frontiers, Plant Science, 4(133):1-19.

Dada, C.A.; Kayode, J. and Arowosegbe, S. (2019). Effects of rooting hormones on the juvenile stem cuttings of Annona muricata Linn. (Annonaceae). World News of Natural Sciences, 23:336-342.

Davies, P.J. (2004). The Plant Hormones: Their Nature, Occurrence and Functions. In: Plant Hormones, Biosynthesis, Signal Transduction, Action. (Davies, P.J., Ed.). Kluwer Academic Publishers, Dordrecht, The Netherlands, pp.1-15.

De Klerk, G.J.; Guan, H.; Huisman, P. and Marinova, S. (2011). Effects of phenolic compounds on adventitious root formation and oxidative decarboxylation of applied indole acetic acid in Malus 'Jork 9'. Plant Growth Regul., 63:175185.

Denaxa, N.K.; Vemmos, S.N. and Roussos, P.A. (2012). The role of endogenous carbohydrates and seasonal variation in rooting ability of cuttings of an easy and a hard to root olive cultivars (Olea europaea L.). Sci. Hort., 143:19-28.

Dunsin, O.; Ajiboye, G. and Adeyemo, T. (2016). Effect of alternative hormones on the rootability of Parkia biglobosa. Sci. Agri., 13(2):113-118.
Eklöf, S; Åstot, C.; Sitbon, F.; Moritz, T.; Olsson, O. and Sandberg, G. (2000). Transgenic tobacco plants coexpressing Agrobacterium iaa and ipt genes have wild-type hormone levels but display both auxin- and cytokinin-overproducing phenotypes. Plant Journal, 23:279-284.

El-Nashar, M.F.M. (2008). Application of Auxins, Vitamins and Bacteria to Hard to Root Cuttings for Commercial Production of Two Ornamental Shrubs. Ph.D. Thesis, Fac. Agric., Assiut Univ., Egypt, 170 p.

Fabbri, A.; Bartolini, G.; Lombardi, M. and Kailis, S. (2004). Olive Propagation Manual. CSIRO Publishing, Melbourne, Aust., 133 p.

Falasca, G.; Reverberi, M.; Lauri, P.; Caboni, E.; De Stradisand, A. and Altamura, M.M. (2000). How Agrobacterium rhizogenes triggers de novo root formation in a recalcitrant woody plant: an integrated histological, ultrastructural and molecular analysis. New Phytologist, 145(1):77-93.

Fales, F.W. (1951). The assimilation and degradation of carbohydrates by yeast cells. J. Bio. Chem., 193(1):113-124.

Gad, M.M. and Ibrahim, M.M. (2018). Effect of IBA and some natural extracts on rooting and vegetative growth of Picual olive sucker and shoot cuttings. Current Sci. Inter., 7(2):191-203.

Gaspar, T. and Hofinger, M. (1988). Auxin metabolism during adventitious rooting. In: Davis, T.D.; B.E. Haissig and N. Sankhla (eds.), Adventitious root formation in cuttings. Portland, Dioscorides Press, pp. 117-131.

Gaspar, T.; Kevers, C.; Penel, C.; Greppin, H.; Reid, D.M. and Thorpe, T.A. (1996). Plant hormones and plant growth regulators in plant tissue culture. In Vitro Cell. Dev. Biol. Plant, 32:272-289.

Gilman, E.F. and Watson, D.G. (1993). Conocarpus erectus, buttonwood. Fact Sheet ST- 179. U.S. Forest Service and 


\section{S.S.A. Abdel-Rahman et al.}

Southern Group of State Foresters, Gainesville, p. 3.

Gollan, J.R. and Wright, J.T. (2006). Limited grazing pressure by native herbivores on the invasive seaweed caulerpa, Taxi folia in a temperate, Aust. Estuary Marine and Freshwater Res., 57(7):685-694.

Gomez, K.A. and Gomez, A.A. (1984). Statistical Procedures for Agricultural Research. $2^{\text {nd }}$ ed. John Wily, NY, 680 p.

Haissig, B.E. (1974). Influence of auxins and auxin synergists on adventitious root primordium initiation and development. New Zealand J. For. Sci., 4(2):311-323.

Hartmann, H.T.; Kester, D.E.; Davies, F.T. and Geneve, R.L. (2014). Hartmann and Kester's Plant Propagation: Principles and Practices, $8^{\text {th }}$ ed. Prentice Hall, New Jersey, USA, pp. 395-399.

Hatta, M.; Beyl, C.A.; Garton, S. and Diner, A.M. (1996). Induction of roots on jujube softwood cuttings using Agrobacterium rhizogenes. J. Hort. Sci., 71(6):881-886.

Hussein, M.F.A. (2018). Improving Seed Germination and Rooting in Cuttings of Some Ornamental Trees. Ph.D. Thesis, Faculty of Agriculture, Assiut University, Egypt, 364 p.

Ibironke, O.A. (2016). Effect of growth promoting substances on selected three ornamental plants. Adv. Crop Sci. and Tech., 4(3):1-4.

Ibironke, O.A. (2019). Root initiation of Bougainvillea from cuttings using different rooting hormones. Adv. Plants Agric. Res., 9(1):121-125.

Izadi, M.; Shahsavar, A.R. and Mirsoleimani, A. (2016). Relation between leaf and stem biochemical constituents and rooting ability of olive cuttings. Int. J. Hort. Sci. Technol., 3(2):231-242.

Jackson, M.L. (1973). Soil Chemical Analysis. Prentic-Hall. Inc, Englewood, Cliffs, U.S.A.
Jiang, K. and Feldman, L.J. (2005). Regulation of root apical meristem development. Annual Review of Cell and Developmental Biology, 21:485-509.

Kasem, M.M. and Abd El-Baset, M.M. (2014). A comparative study to improve rooting of English lavender stems cuttings. African J. Agric. Res., 9(50):3632-3637.

Kelen, M. and Ozkan, G. (2003). Relationships between rooting ability and changes of endogenous IAA and ABA during the rooting of hardwood cuttings of some grapevine rootstocks. European Journal Horticultural Science, 68(1):8-13.

Khan, W.; Rayirath, U.P.; Subramanian, S.; Jithesh, M.N.; Rayorath, P.; Hodges, D.M.; Critchley, A.T.; Craigie, J.S.; Norrie, J. and Prithiviraj, B. (2009). Seaweed extracts as biostimulants of plant growth and development. J. Plant Growth Regul., 28(4):386-399.

Kobayashi, K.D.; McConnel, J. and Griffis, J. (2007). Bougainvillea. Ornamental flower, 38:1-12.

Kurepin, L.V.; Zaman, M. and Pharis, R.P. (2014). Phytohormonal basis for the plant growth promoting action of naturally occurring biostimulators. J. Sci. Food and Agric., 94(9):1715-1722.

Lima, C.C.; Ohashi, S.T.; Simões, P.H.O.; Jucoski, G.O.; Silva, P.A.; Silva, J.P.; Silva, C.R.; Nogueira, G.A.S.; Nascimento, V.R.; Brito, A.E.; Palheta, L.F. and Neto, C.F.O. (2019). Effect of indole-3-butyric acid (IBA) on rooting of cuttings of Schizolobium parahyba var. amazonicum (Huber ex Ducke) Barneby. Australian J. Crop Sci., 13(5):761-766.

Liu, C.F.; Zhu, J.Y.; Liu, Z.L.; Li, L.; Pan, R.C. and Jin, L.H. (2002). Exogenous auxin effects on growth and phenotype of normal and hairy roots of Pueraria lobata (willd.) Ohwi. Plant Growth Regul., 38(1):37-43.

Liu, Z.H.; Wang, W.C. and Yen, Y.S. (1998). Effect of hormone treatment on 
root formation and endogenous indole-3acetic acid and polyamine levels of Glycine max cultivated in vitro. Bot. Bull. Acad. Sin., 39:113-118.

Massoud, H.Y.A.; Abd El-Baset, M.M. and Ghozzy, A.A. (2017). Effect of some natural products as an alternative chemical growth regulators on rooting response, growth and chemical composition of rosemary cutting. J. Plant Production, Mansoura Univ., 8(8):797803.

Mohamed, S.M.; Youssef, A.S.M. and Hegazy, N.E. (2014). Effect of IBA, rooting media and planting date on vegetative propagation of button wood tree (Conocarpus erectus L.). Annals of Agric. Sci., Moshtohor, 52(1):123-132.

Nelson, G. (1996). The Shrubs and Woody Vines of Florida. Pineapple Press, Inc., Sarasota, Fl., 391 p.

O'Brien, T.P. and McCully, M.E. (1981). Study of Plant Structure: Principles and Selected Methods Termarcarphi, Pty. LTD., Melbourne, pp. 789-791.

Ogunwa, O.B. (2011): Stimulation of rooting in Bougainvillea spectabilis and $B$. glabra using coconut water, B.Sc. Projet, University of Agriculture, Abeokuta, Ogun State.

Pacholczak, A. and Pietkiewicz, S. (2014). Gas exchange during rhizogenesis in common ninebark stem cuttings treated with biostimulators. Propagation of Ornamental Plants, 14(2):90-96.

Pacholczak, A.; Nowakowska, K.; Mika, N. and Borkowska, M. (2016). The effects of the biostimulator Goteo on the rooting of ninebark stem cuttings. Folia Hort., 28(2):109-116.

Pacholczak, A.; Szydło, W.; Jacygrad, E. and Federowicz, M. (2012). Effect of auxins and the biostimulator Algamino Plant on rhizogenesis in stem cuttings of two dogwood cultivars (Cornus alba 'Aurea' and 'Elegantissima'). Acta Sci. Pol. Hortorum Cultus., 11(2)93-103.
Petridou, M.K. and Porlingis, I. (1997). Presowing application of gibberellic acid on seeds used for the mung bean bioassay, promotes root formation in cuttings. Sci. Hortic., 70:203-210.

Ponce, G.; Barlow, P.W.; Feldman, L.J. and Cassab, G.I. (2005). Auxin and ethylene interactions control mitotic activity of the quiescent centre, root cap size and pattern of cap cell differentiation in maize. Plant, Cell and Environment, 28:719-732.

Raven, P.H.; Evert, R.F. and Eichhorn, S.E. (2005). Biology of Plants, $7^{\text {th }}$ ed. New York: Freeman, 686 p.

Reuveni, O. and Adato, I. (1974). Endogenous carbohydrates, root promoters and root inhibitors in easy-and difficult-to-root date palm (Phoenix dactylifera L.) offshoots. J. Amer. Soc. Hot. Sci., 99(4):361-363.

Sarmast, M.K.; Salehi, H. and Khosh-Khui, M. (2012). In vitro rooting of Araucaria excelsa R. Br. using Agrobacterium rhizogenes. J. Central Europe. Agric., 13:123-130.

Sarmast, M.K.; Kordkatooli, R.; Rezaei, Z. and Ghasemnezhad, A. (2019). Effect of seasons, gender and Agrobacterium rhizogenes strains on adventitious root induction of male and female Juniperus communis L. J. Orna. Plants, 9(1):23-31.

Scagel, C.F. and Linderman, R.G. (1998). Influence of ectomycorrhizal fungi inoculation on growth and root IAA concentrations of transplanted conifers. Tree Physiol., 18:739-747.

Setiawati, T.; Keliat, A.P.R.; Budiono, R.; Partasasmita, R. and Iskandar, J. (2018). Influence of NAA and coconut water with variation of soaking duration on the growth of yellow bamboo branch cutting. Nusantara Bioscience, 10:178-182.

Singh, K.S. (2017). Multiplication of phalsa (Grewia asetica L.) cv. Dwarf type through hardwood stem cutting under Srinagar Garhwal Himalayas. International Journal of Current 
Microbiology and Applied Sciences, 6(2):1173-1178.

Snedecor, G.W. and Cochran, W.G. (1973). Statistical Methods. Sixth Edition, Iowa State Univ., Press, Ames., Iowa, USA.

Sokhuma, P.; Intorrathed, S. and Phonpakdee, R. (2018). Effect of IBA and NAA on rooting and axillary shoot outgrowth of 'Himalayan' mulberry stem cutting. Inter. J. Agric. Tech., 14(7):1939-1948.

Spaepen, S.; Vanderleyden, J. and Okon, Y. (2009). Plant growth-promoting actions of rhizobacteria. Advances Bot. Res., 51:283-320.

Strick, W.A.; Staden, J. and Wani (1997). Screening of some South African seaweeds for cytokinin like activity. South Africa J. Botany, 63(3):161-164.

Tilahun, A.; Manahlie, B.; Abebe, G. and Negash, G. (2019). Effect of cutting position and indole butyric acid (auxin) concentration on rooting response of Araucaria heterophylla. African J. Biotech., 18(4):86-91.

Trobec, M.; Stampar, F.; Veberic, R. and Osterc, G. (2005). Fluctuations of different endogenous phenolic compounds and cinnamic acid in the first days of the rooting process of cherry rootstock 'Gisela 5' leafy cuttings. J. Plant Physiol., 162:589-597.

Vasco, C.; Ruales, J. and Kamal-Eldin, A. (2008). Total phenolic compounds and antioxidant capacities of major fruits from Ecuador. Food Chemistry, 111:816-823.

Wróblewska, K. (2015). Benzyladenine effect on rooting and axillary shoot outgrowth of Gaura lindheimeri Engelm. A. Gray cuttings. Acta Sci. Pol., Hortorum Cultus, 12(3):127-136.

Yasin, S.A. and Al-Azawi, A.H. (2019). Antibacterial activity of Conocarpus erectus leaves extracts on some microorganisms isolated from patients with burn infection. Plant Archives, 19(2):583-589.

Yong, W.H.J.; Liya, G.; Yan, N.F. and Swee, N.T. (2013). The composition of plant growth regulators in coconut water. Parsons Laboratory, Department of Civil and Environmental Engineering, MIT, Cambridge, MA 02139, USA 3 Natural Sciences and Science Education, Nanyang Technological University, Nanyang Walk, Singapore.

Yoo, Y.K. and Kim, K.S. (1996). Seasonal variation in rooting ability, plant hormones, carbohydrate, nitrogen, starch and soluble sugar contents in cuttings of white Forsythia (Abeliophyllum distichum Nakai). J. Kor. Soc. Hort. Sci., 37(4):554-560.

Zengibal, H. and Özcan, M. (2006). The effect of IBA treatments on rooting of hardwood cuttings in kiwifruit (Actinidia deliciosa, A. Chev.). J. Fac. Agric., OMU, 21(1):40-43.

Zhang, Z.; Wang, Z.; Zhang, Q. and Lin, R. (1998). Rapid separation and quantification of the internal hormones from tartary buckwheat leaf using high performance liquid chromatography. Proc. VII Inter. Symposium on Buckwheat, Advances in Buckwheat Res., Winnipeg, Manitoba, Canada. 


\section{تحسين تجذير ونمو عقل الكونوكاربس باستخدام إندول حمض البيوتيريك وبعض المنشطات الحيوية}

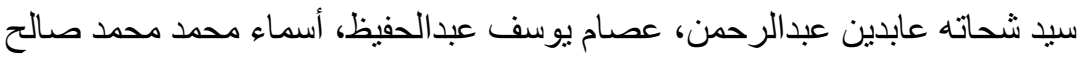

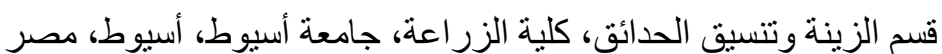

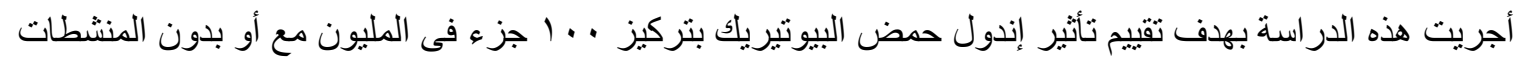

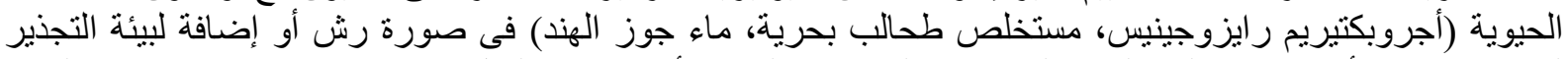

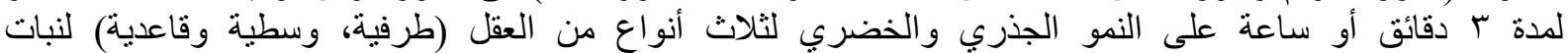

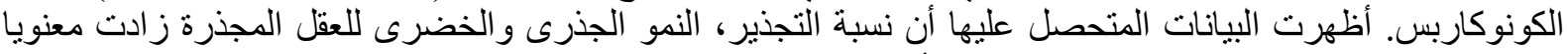

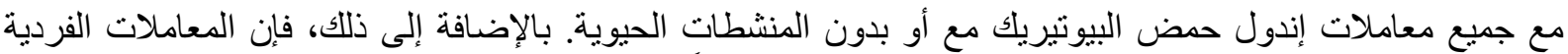

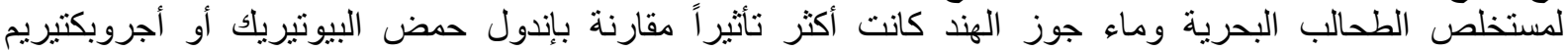

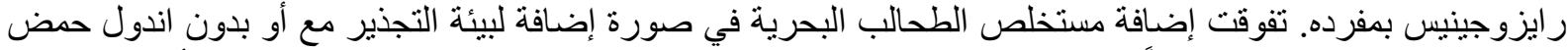

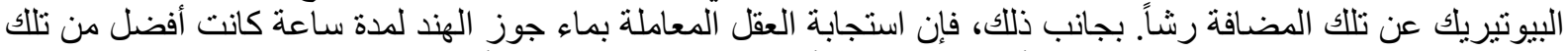

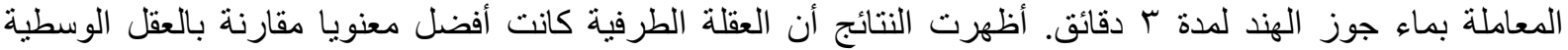

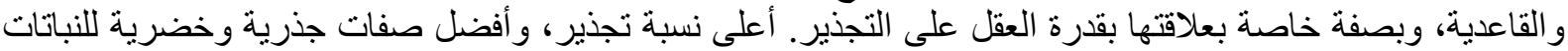

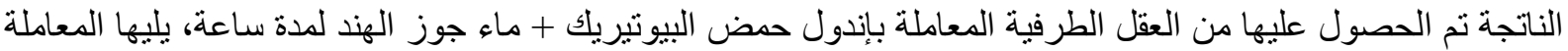

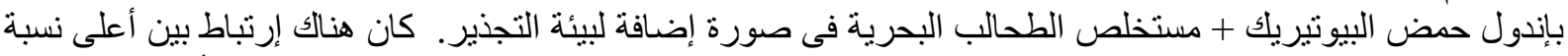

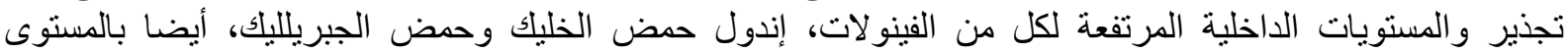

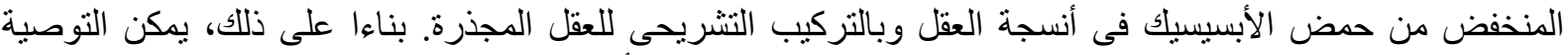

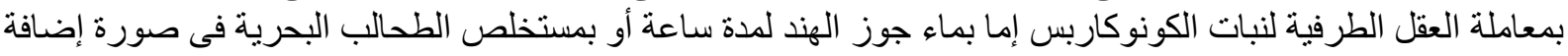
لبيئة التجذير بالإشتر الك مع إندول حمض البيوتيريك بهدف تعظيم نسبة التجذير، صفات التئ النمو الجذرى و الخضرى، كذللك المحتوى الداخلى للمو اد المنشطة للتجذير. 